\title{
KLASIFIKASI KETERPAKAIAN MODUL E-LEARNING BERBASIS MOODLE DENGAN PENDEKATAN TEXT MINING
}

\author{
Enda Esyudha Pratama
}

Jurusan Informatika, Fakultas Teknik, Universitas Tanjungpura

enda@informatika.untan.ac.id

\begin{abstract}
Abstrak
Pandemi COVID-19 memberikan dampak pada berbagai bidang termasuk dunia pendidikan. Salah satu kebijakan yang harus dilakukan adalah melarang proses belajar tatap muka dan menggantinya dengan pembelajaran daring. Universitas Tanjungpura sebagai salah satu institusi pendidikan memfasilitasi kebijakan ini dengan menyediakan fasilitas sistem e-learning. Sistem e-learning di UNTAN menggunakan platform Moodle. Salah satu informasi yang dibutuhkan terkait pengelolaan e-learning adalah keterpakaian modul. Sebuah modul dapat dianggap dipakai atau digunakan apabila memiliki fitur atau aktivitas seperti lesson, assignment, quiz, forum, file, dan rencana pembelajaran semester (RPS). Standar atau acuan ini berdasarkan parameter yang dibuat oleh Pusat E-Learning UNTAN. Fitur-fitur tersebut dapat dideteksi dengan cara mengambil (crawling) data tampilan setiap modul dalam bentuk kode HTML. Data kode HTML ini bersifat tidak terstruktur. Metode text mining digunakan untuk mengolah data yang bersifat tidak terstruktur tersebut menjadi informasi yang dibutuhkan. Informasi tersebut berupa fitur-fitur yang digunakan pada suatu modul. Pada setiap fitur yang digunakan akan dilakukan scoring sebagai dasar keterpaakain suatu modul. Tujuan dari penelitian ini adalah menghasilkan aplikasi yang dapat mengklasifikasi keterpakaian modul e-learning secara otomatis dengan pendekatan text mining untuk pengolahan data yang digunakan. Berdasarkan hasil pengujian dengan mengambil sampling 5 modul pada tiap fakultas, didapat kinerja algoritma dalam mengklasifikasikan kateogri modul secara benar sebesar $88,89 \%$. Hal ini dapat dikatakan algoritma dapat bekerja secara baik.
\end{abstract}

Kata kunci : e-learning, moodle, modul, klasifikasi, text mining

\section{Pendahuluan}

Pandemi COVID-19 memberikan dampak pada berbagai bidang termasuk dunia pendidikan. Pemerintah Indonesia telah mengeluarkan beberapa kebijakan terkait penanganan wabah virus ini. Pada tanggal 24 maret 2020, Menteri Pendidikan dan Kebudayaan Republik Indonesia mengeluarkan Surat Edaran Nomor 4 Tahun 2020 Tentang Pelaksanaan Kebijakan Pendidikan Dalam Masa Darurat Penyebaran COVID-19, dalam Surat Edaran tersebut menunda proses belajar tatap muka dan menggantinya dengan pembelajaran daring. Universitas Tanjungpura sebagai salah satu institusi pendidikan memfasilitasi kebijakan ini dengan menyediakan sistem e-learning bagi dosen dan mahasiswa dalam melaksanakan perkuliahan daring. E-learning merupakan kegiatan pembelajaran secara elektronik atau disebut e-learning telah dikenal pada tahun 1970-an, namun di Indonesia baru memulainya pada tahun 1995-an. Menurut Afriansyah (2019), e-learning berasal dari huruf "e" yang berarti elektronik dan "Learning" yang berarti pembelajaran, jadi e-learning adalah pembelajaran yang menggunakan jasa elektronika. Lebih lanjut menurut Putri (2020), mengemukakan pendapat/gagasan tentang pembelajaran elektronik, antara lain adalah: "internet based learning" (belajar berbasis internet), "virtual learning" (belajar melalui lingkungan maya), dan "web-based learning" (belajar berbasis web). Beberapa ahli mengemukakan bahwa istilah "e-learning" mengacu pada penggunaan teknologi internet untuk menyajikan sejumlah pilihan solusi yang sangat luas yang mengarahkan pada peningkatan pengetahuan. Menurut Inggriyani (2019), mengemukakan bahwa e-learning adalah bentuk kegiatan pembelajaran yang memanfaatkan jaringan, seperti: internet, Local Area Network (LAN), atau Wider Area Network (WAN) sebagai metode penyampaian, interaksi, dan fasilitasi, serta didukung oleh berbagai layanan belajar. pembelajaran yang menggunakan alat-alat elektronik yang penggunaannya saat ini mengarah pada penggunaan komputer dan jaringan internet sehingga pendidik dan peserta didik berada dalam sebuah jaringan yang sama.

Berbagai macam tools, aplikasi, maupun platform dapat digunakan untuk memfasilitasi sistem e-learning ini. Sistem e-learning di UNTAN menggunakan platform Moodle untuk mengakomodir kebutuhan sistem pembelajaran daring. MOODLE (Modular Object Oriented Dynamic Learning Environment) adalah seperangkat lunak yang berguna untuk membuat dan 
mengadakan kursus/ pelatihan/ pendidikan berbasis internet (Fatmawati, 2019). Pengembangannya didesain untuk mendukung kerangka konstruksi sosial, dalam pendidikan MOODLE termasuk intranet dalam model CAL+CAT (Computer Asisted Learning+ Computer Asisted Teaching) yang disebut dengan LMS (Learning Management System) (Muhammad, 2020). Karakter utama LMS adalah pengguna yang merupakan pengajar dan siswa, dan keduanya harus terkoneksi dengan internal menggunakan aplikasi ini. MOODLE dapat diberikan secara gratis sebagai perangkat lunak open source (dibawah lisensi GNU Public Licence). Di dalam MOODLE terdapat berbagai fasilitas yang didesain untuk memberi kemudahan bagi pengguna dalam mengelola kegiatan didalamnya (Sara, 2020). Beberpa aktivitas pembelajaran yang didukung oleh MOODLE seperti fitur forum, assignment, kuis, lesson, file, survey, feedback, presenxi, dll.

Proses evaluasi merupakan salah satu tahapan penting dalam analisa penggunaan sistem e-learning di UNTAN. Salah satu informasi yang dibutuhkan dari proses evaluasi adalah keterpakaian modul dalam sistem e-learning. Modul yang aktif atau tersedia belum tentu digunakan. Moodle sendiri mempunyai fitur statsitik untuk memberikan informasi terkait aktivitas user (dosen dan mahasiswa) pada setiap modul. Namun belum ada informasi terkait kategori modul digunakan atau tidak. Informasi mengenai keterpakaian tersebut juga diperlukan berdasarkan pengelompokan tahun ajaran, fakultas, dan program studi.

Acuan dari Pusat E-Learning UNTAN terkait keterpakaian sebuah modul adalah minimal memiliki dua buah fitur dari beberapa pilihan fitur seperti lesson, assignment, quiz, forum, file, dan rencana pembelajaran semester (RPS). Untuk dapat mendeteksi apakah sebuah modul memiliki fitur tersebut, maka akan dilakukan pengambilan data dari HTML element. Data tersebut kemudian diolah menjadi informasi yang dibutuhkan. Bentuk data yang didapat berupa teks tidak terstruktur (unstructured text) (Priyanto \& Ma'arif, 2018). Untuk dapat mengolahnya diperlukan metode text mining. Text mining merupakan metode analisis teks yang dilakukan secara otomatis oleh komputer untuk menggali informasi yang berkualitas dari suatu rangkaian teks yang terangkum dalam sebuah dokumen Riski, et al (2019). Text mining berusaha untuk mengekstrak informasi yang berguna dari sumber data melalui identifikasi dan eksplorasi pola yang menarik Pemanfaatan text mining dapat digunakan untuk menyelesaikan masalah-masalah seperti analisis, klasifikasi, klastering, maupun prediksi Pratama, et al (2021). Menurut Deolika, et al (2019), tahapan text mining secara umum terdiri dari tiga bagian utama yakni text preprocessing, feature selection, dan text analytic.
Text preprocessing adalah tahapan yang berfungsi untuk membersihkan teks sebelum diolah lebih lanjut. Data teks mentah yang tidak terstruktur memiliki cukup banyak noise seperti tanda baca, angka, imbuhan, karakter-karakter khusus, slang word dan lain sebagainya. Adapun tahapan lebih detailnya yaitu Transform Case, Tokenizing, dan Filtering (Hidayatullah, 2016). Transform Case merupakan proses mengubah semua karakter menjadi karakter tertentu yang seragam. Tokenizing merupakan proses penguraian deskripsi yang semula berupa kalimat - kalimat menjadi kata-kata. Sedangkan Filtering yaitu proses seleksi terhadap kata-kata yang tidak memiliki makna atau arti yang berpengaruh dalam sebuah teks.

Dalam text mining, feature selection merupakan tahapan yang paling penting yang memiliki peran yang sangat signifikan dalam akurasi text analytic (Somantri, et al (2017). Feature mempunyai pegaruh penting dalam pembobotan kata. Pembobotan fitur merupakan sebuah proses pemberian nilai pada setiap fitur berdasarkan relevansi dan pengaruhnya terhadap hasil klasifikasi. Nilai tersebut nantinya dapat digunakan sebagai dasar untuk melakukan seleksi fitur berdasarkan minimum bobot yang telah dihitung dari setiap fitur. Semakin sering sebuah fitur muncul dalam sebuah teks, maka semakin besar pula bobot yang akan didapat,yang artinya maka akan semakin penting pula fitur tersebut dalam sebuah kalimat. Empat pendekatan yang paling umum digunakan dalam feature selection adalah Document Frequency (DF), Term Frequency (TF), Inverse Document Frequency (IDF) dan Term Frequency/Inverse Document Frequency (TF/IDF) (Hormansyah, et al (2018). Pada penelitian ini, pendekatan yang digunakan adalah Term Frequency (TF) untuk menghitung frekuensi kemunculan kata. Tahapan terakhir dari proses text mining adalah text analytic. Dalam tahapan ini data teks yang sudah dibersihkan dan diidentifikasikan berdasarkan term/kata kunci yang menjadi ciri dokumen teks tersebut diolah dengan menggunakan berbagai macam algoritma untuk berbagai kebutuhan analisis Prameswari, et al (2021). Pada penelitian ini, analisis digunakan untuk melihat term-term mana saja yang dominan muncul dan keterkaitannya dengan kondisi di lapangan. Proses analisis ini dilakukan dengan bantuan visualisasi agar lebih mempermudah.

Berdasarkan penjelasan yang telah disampaikan, maka beberapa permasalahan yang ditemukan yaitu belum adanya parameter penentuan klasifikasi keterpakaian sebuah modul di platform elearning Moodle. Selain itu, permasalahan lainnya adalah modul yang perlu dievaluasi pada setiap semester berjumlah lebih dari 1000 modul untuk tiap semesternya. Tentu hal ini akan menyulitkan jika perlu melihatnya satu persatu oleh manusia. 
Beberapa penelitian terkait tentang klasifikasi pada kasus dataset e-learning telah dilakukan. Penelitian yang dilakukan oleh Putri (2020) menghasilkan model untuk klasifikasi multi label gaya belajar yang pada umumnya di Indonesia, yaitu gaya belajar Visual, Auditori, dan Kinestetik (VAK) dengan menggunakan metode supervised learning, antara lain k-Nearest Neighbours (k-NN), Support Vector Machine (SVM), dan Decision Trees (DTs). Data log yang digunakan merupakan data log mahasiswa kedokteran pada Learning Management System (LMS) Universitas Nairobi dengan spesifikasi data log standar LMS Universitas Nairobi. Sedangkan penelitian oleh Ferdino (2019) mencoba mengklasifikasin user feedback berdasarkan kuesioner yang disebar pada platform elearning. Dari kedua penelitian tersebut, dapat dianalisa bahwa platform e-learning menyediakan banyak data yang dapat diolah untuk menjadi sebuah informasi yang bernilai. Adapun yang menjadi fokus pada penelitian ini adalah jenis dan tujuan klasifikasi serta dataset yang digunakan berbeda dari penelitian sebelumnya.

Pada penelitian ini, fokus jenis dan tujuan klasifikasi adalah untuk mengetahui keterpakaian modul e-learning secara otomatis menggunakan pendekatan metode text mining. Sedangkan dataset yang digunakan bersumber dari kode HTML tampilan courses. Metode text mining digunakan untuk mengolah data teks tidak terstruktur (kode HTML) menjadi terstruktur sehingga menghasilkan informasi yang dibutuhkan. Informasi tersebut nantinya akan dijadikan acuan untuk mengelompokan kategori keterpakain setiap modul e-learning berbasis Moodle. Sistem ini nantinya juga dapat memberikan informasi terkait rekapitulasi informasi modul berdasarkan tahun ajaran, fakultas, dan program studi serta kualitas modul berdasarkan nilai (scoring)

\section{Metodologi Penelitian}

\subsection{Pengumpulan Data}

Data yang digunakan pada penelitian ini bersumber dari courses atau modul pada platform Moodle. Adapun struktur modul atau courses dikelompokan berdasarkan tahun ajaran, fakultas, dan program studi. untuk dapat mengaakses suatu modul, maka diperlukan id atau kode untuk setiap modul dan program studi. Proses pengambilan data secara otomatis dilakukan pada setiap modul untuk setiap program studi. Pembatasaan proses secara otomatis dengan parameter program studi ini dilakukan untuk menghindari kinerja sistem menjadi error atau crash karena menerima request yang terlalu besar dikarenakan kompleksitas kinerja algoritma yang tinggi.

Dengan menggunakan asumsi hasil observasi dimana pada setiap progam studi paling banyak memuat 50 modul, maka proses crawling akan dilakukan per program studi. Dari proses crawling ini nantinya akan didapat list id kode modul atau mata kuliah pada progam studi tersebut. Setelah didapat list kode setiap mata kuliah atau modul dari suatu program studi, maka langkah selanjutnya adalah melakukan pengambilan data dari kode HTML untuk tiap modul.

Data yang diperlukan terkait syntax kode HTML yang menampilkan aktivitas atau fitur Lesson, Assignment, Quiz, Forum, File, dan RPS. Tampilan modul yang aktif secara default akan menampilkan berbagai macam aktivitas di dalam platform Moodle. Aktivitas tersebut akan ditampilkan secara menyeluruh pada saat modul diakses. Kode HTML yang menampilan aktivitas tersebut dapat langsung terdeteksi pada tampilan kode sumber.

\subsection{Rancangan Sistem}

Pada tahap perancangan sistem, dilakukan proses identifikasi pada setiap tahapan agar proses implementasi dapat berjalan baik. Setiap proses tahapan pernacangan digambarkan dalam bentuk yang lebih ringkas menggunakan diagram alir sistem. Adapun diagram alur sistem yang dirancang dapat dilihat pada Gambar 1 .

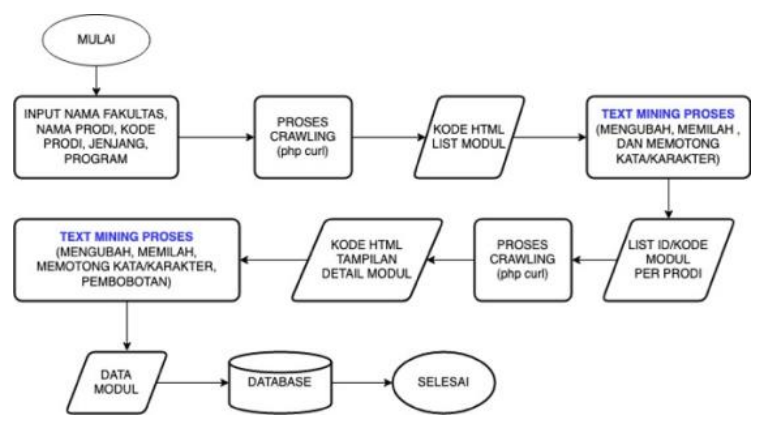

Gambar 1. Diagram alur sistem

Proses tahapan dalam kerja sistem diawali dengan menerima masukan dari pengguna. Berdasarkan analisa yang telah dilakukan pada tahap pengumpulan data, sistem membutuhkan masukan berupa nama fakultas, nama prodi, kode prodi, jenjang, dan program. Masukan ini berupa parameter yang berguna bagi sistem untuk melakukan proses selanjutnya yang dilakukan secara otomatis.

Setelah sistem mendapatkan parameter masukan, maka selanjutnya sistem akan bekerja secara otomatis dimulai dari proses crawling. Proses crawling dilakukan dengan memanfaatkan function dari PHP yaitu curl. Fungsi ini berguna untuk mengambil semua kode sumber HTML dari sebuah website dengan parameter url. Hasil dari proses crawling ini berupa kode HTML. Kode HTML ini tidak akan memiliki nilai jika tidak diproses lebih lanjut. Di dalam kode HTML ini terdapat data 
berupa id dari setiap matakuliah dari suatu program studi. ID ini nantinya berguna sebagai parameter masukan untuk mengidentifikasi keterpakaian suatu modul.

Berdasarkan dari struktur kode HTML yang telah didapat, tahapan selanjutnya dilakukan penerapan metode text mining yang berguna untuk membaca dan mengambil kode-kode yang dibutuhkan sebagai proses pengecekan keterpakaian suatu modul. Kode-kode yang dibutuhkan tersebut juga akan membantu dalam proses scoring suatu modul. Suatu modul dikatakan digunakan jika skor nilai yang didapat lebih dari 0 . Artinya terdapat minimal satu macam aktivitas yang digunakan pada modul tersebut.

Terdapat dua kali pendekatan proses text mining pada penelitian ini. Proses pertama digunakan untuk mendapatkan list kode mata kuliah dari suatu program studi. List kode tersebut disusun dalam bentuk array. Proses kedua terdapat pada tahap mengidentifikasi activity yang terdapat pada setiap modul. Proses text mining akan memproses activity apa saja yang terdapat pada setiap modul berdasarkan ketersediaanya pada kode sumber HTML. Data-data yang telah didapat dari proses pengolahan tersebut nantinya akan disimpan ke dalam sebuah database. Database yang digunakan dalam penelitian ini yaitu MySQL.

Pada tahap evaluasi, akan dilakukan skenario pengujian dimana akan dibandingkan hasil klasfikasi keterpakaian secara otomatis oleh sistem dengan hasil klasifikasi oleh user atau pemahaman manusia. Untuk proses pengujian akan dilakukan terhadap 5 modul dari 9 fakultas sehingga total modul yang digunakan dalam proses pengujian sebanyak 45 modul. Nilai akurasi daripada kinerja algoritma yang dibangun akan dihitung berdasarkan perbandingan jumlah modul yang diklasifikasikan secara benar oleh sistem terhadap total seluruh modul yang digunakan sebagai data uji.

\section{Hasil dan Pembahasan}

Tahapan awal dari implementasi yaitu membangun aplikasi berdasarkan algoritma yang telah disusun. Berdasarkan diagram alir sistem, untuk tahap awal dibutuhkan masukan dari user atau pengguna berupa nama fakultas, nama program studi, kode atau id program studi berdasarkan Moodle, program, dan jenjang. Untuk melihat kode atau id prodi, user dapat mengakses alamat https://elearning.untan.ac.id/learning/. Pada tampilan halaman tersebut akan ditampilkan semua list category yang sudah dibuat pada platform e-learning Moodle. Adapun tampilan input untuk mengakomodir masukan data dari pengguna dapat dilihat pada Gambar 2.

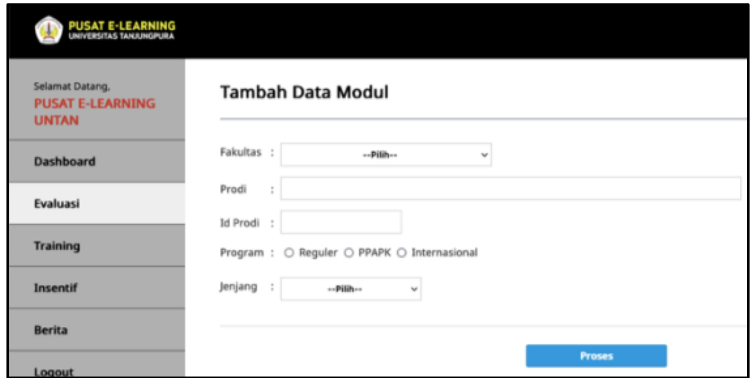

Gambar 2. Tampilan input data

Masukan ini berguna bagi aplikasi sebelum melakukan proses crawling secara otomatis untuk mendapatkan data dari kode HTML yang dibutuhkan. Setelah data dimasukan, maka untuk memulai proses crawling hingga text mining secara otomatis, pengguna dapat menekan tombol proses. Aplikasi akan secara otomatis menjalankan serangkaian tahapan dari algoritma yang telah disusun.

Pada bagian awal kode program didefinisikan terlebih dahulu fungsi untuk mengambil kode HTML dengan parameter URL dari website yang akan diambil. Adapun url atau alamat untuk menampilkan list matakuliah atau modul yaitu : https://e-

learning.untan.ac.id/learning/course/mangement.php ?categoryid=. Selain itu, untuk dapat mengakses data modul pada platform Moodle, diperlukan autentikasi user pengelola atau administrator agar dapat mengakses seluruh modul. Akses username dan password dimasukan didalam script pada fungsi "CURL_POSTFIELDS". Setelah proses autentikasi berhasil, akses login dsimpan di dalam cookie browser agar selama menjalankan proses crawling tidak perlu melakukan proses login atau autentikasi berulang-ulang.

Tahapan proses text mining dilakukan dengan menggunakan beberapa fungsi default dari PHP. Diawalai dengan tahapan text-preprocessing atau pengeolahan kata pada tahap awal. Pada tahap ini terdapat beberapa proses seperti mengubah bentuk kata. Fungsi str_replace() digunakan untuk mengganti suatu karakter dengan karakter lain yang ditentukan. Fungsi ini digunakan untuk menyeragamkan karakter yang akan diambil. Sedangkan fungsi explode() digunakan untuk memecah atau memotong kata dan menyimpannya dalam bentuk nilai array dalam sebuah variabel. Hal ini termasuk dalam proses tokenizing.

Untuk mengambil id dari setiap mata kuliah, diperlukan acuan dimana id itu berada. Dalam hal ini, letak id berada setelah kode "\$amp;courseid=". Maka kode tersebut menjadi acuan atau parameter bagi fungsi explode untuk memecah suatu kode HTML yang lengkp menjadi bagian-bagian kecil.

Selanjutnya digunakan fungsi substr() untuk mengambil karakter dengan jumlah panjang karakter tertentu. Jika dilihat pola yang terbentuk, maka id 
mata kuliah atau modul pada setiap bagian terdapat pada 5 karakter awal. Maka fungsi substr() dapat mengakomodir hal ini dengan menyertakan parameter posisi awal karakter yang mau diambil dan sepanjang apa karakter mau diambil. Sehingga fungsi nya menjadi substr("\$data",0,4). Kemudian setiap id mata kuliah atau modul tersebut disimpan dalam sebuah variabel dalam bentuk array.

Proses selanjutnya bertujuan untuk mendeteksi activity yang dimiliki pada setiap mata kuliah atau modul. Setelah data id modul didapat, maka id tersebut dijadikan acuan dalam sebuah url. Adapun url atau alamat untuk tampilan sebuah modul yaitu : learning.untan.ac.id/learning/course/view.php?id=23

. Dengan menggunakan id yang telah didapat pada proses sebelumnya, maka akan dilakukan proses pengulangan (looping) untuk membaca setiap tampilan sebuah modul sejumlah kode id mata kuliah yang didapat.

Pada setiap mata kuliah atau modul yang sedang dibuka atau diakses, umumnya semua activity akan tampil pada halaman utama. Jika dilihat pada kode sumber HTML, maka akan terdapat tulisan Forum, Quiz, Assignment, dsb. Tulisan-tulisan ini yang akan dijadikan acuan untuk fungsi explode dalam memecah karakter nantinya. Pada proses awal dilakukan fungsi str_replace() untuk mengubah karakter "<" atau ">" menjadi karakter tertentu agar tidak menggangu script saat dijalankan karena karakter tersebut terdeteksi sebagai pembuka dan penutup tag kode HTML.

Setelah karakter-karakter diubah atau dibersihkan, maka proses selanjutnya adalah pengambilan data berdasarkan karakter tertentu. Data judul didapat menggunakan fungsi explode() dengan acuan parameter "\&60/title\&62". Data forum didapat menggunakan fungsi explode() dengan acuan parameter "Forum". Khusus untuk fitur forum akan dilakukan pengecekan lebih dari dua kali digunakan untuk dapat diberi nilai atau bobot. Hal ini dikarenakan fitur forum secara default tersedia pada modul yang diaktifkan meskipun tidak digunakan. Data tugas didapat menggunakan fungsi explode() dengan acuan parameter "Assignment". Data kuis didapat menggunakan fungsi explode() dengan acuan parameter "Quiz\&60/span". Data file didapat menggunakan fungsi explode() dengan acuan parameter "File\&60/span". Data lesson didapat menggunakan fungsi explode() dengan acuan parameter "Lesson\&60/span". Data RPS didapat menggunakan fungsi explode() dengan acuan parameter "RPS".

Setiap fitur yang telah terdeteksi pada proses sebelumnya tersebut kemudian dilakukan proses pembobotan. Setiap kata yang terdeteksi maka akan diberi nilai bobot satu. Sehingga jika suatu modul memiliki 6 fitur aktivitas maka akan mendapatkan nilai bobot score 6. Jika score diatas nilai 2, maka data status akan diisi sebagai "Digunakan". Namun jika score dibawah atau sama dengan 2 maka statusnya akan dikelompokan sebagai "Aktif". Kemudian data-data yang telah didapat tersebut disimpan ke dalam database. Data yang disimpan dalam database yaitu : tahun ajaran, fakultas, program studi, jenjang, program, id/kode matkul, judul matakuliah, score, status, dan fitur. Adapun contoh tampilan data hasil proses dapat dilihat pada Gambar3.

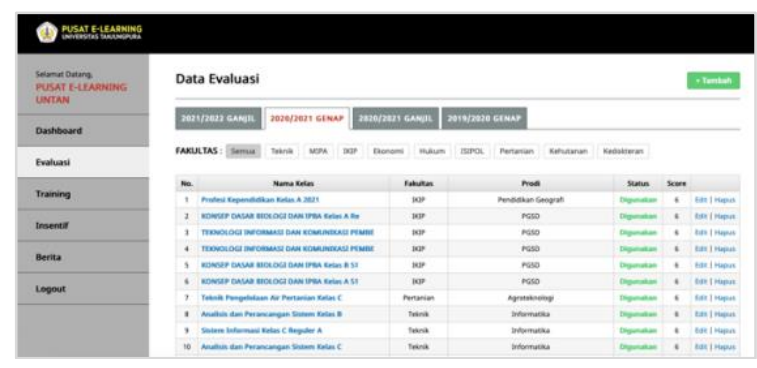

Gambar 3. Tampilan data hasil klasifikasi keterpakaian modul

Data score, nama modul, dan link/url modul didapat secara otomatis dari hasil proses text mining. Data score digunakan untuk mengurutkan modul dari yang tertinggi hingga terendah. Data url/link modul dapat digunakan untuk melihat tampilan modul pada platform Moodle. Link url ditautkan pada nama modul. Sedangkan data nama fakultas, tahun ajaran, program, dan jenjang didapat dari input user atau pengguna.

Data dapat dilihat dalam bentuk pengelompokan yang lebih detail berdasarkan fakultas dan program studi. Pada tampilan rekapitulasi, data dapat dilihat berdasarkan tahun ajaran, fakultas dan program studi. Pada tampilan detail informasi modul dapat dilihat secara lengkap data dari setiap modul.

Selain itu, terdapat pula informasi terkait fitur-fitur atau aktivitas yang digunakan di dalam modul tersebut. Tampilan detail informasi ini juga dapat digunakan untuk mengubah data jika terdapat ketidaksesuaian data hasil crawling oleh mesin.

Sistem juga dapat menampilkan rekapitulasi data dalam bentuk tampilan grafik pada menu dashboard. Visualisasi dalam bentuk grafik akan mempermudah dan mempercepat seseorang dalam menangkap informasi yang disampaikan.

Dalam hal ini informasi yang dapat dilihat adalah terkait total keseluruhan modul yang aktif dan digunakan disajikan dalam bentuk tampilan bar chart. Data dikelompokan untuk setiap semester. Grafik akan menampilkan perbandingan antara data modul aktif dan digunakan untuk tiap semesternya.

Selain itu terdapat visualisasi grafik dalam bentuk pie chart untuk melihat data berdasarkan fakultas dan program studi. Tampilan visualisasi grafik ini akan mempermudah untuk mendapatkan informasi secara cepat terkait fakultas mana yang memiliki jumlah modul paling banyak atau paling 
sedikit pada setiap semesternya. Adapun tampilan visualisasi data dalam bentuk grafik dapat dilihat pada Gambar 4.

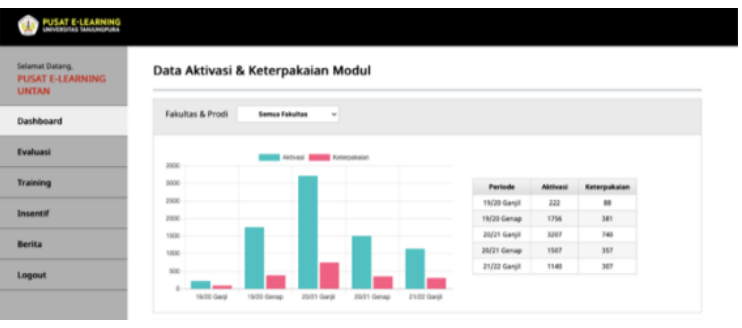

Gambar 4. Tampilan rekap data dalam bentuk visualisasi grafik

Dari hasil proses implementasi yang dilakukan, terlihat aplikasi dengan menggunakan algoritma yang dibangun dapat melakukan proses klasifikasi keterpakaian modul e-learning secara otomatis. Algoritma mampu mendeteksi jumlah modul yang diaktifkan pada tahun ajaran 2020/2021 sebanyak 4714 modul aktif. Hal ini hampir sama persis dengan perhitungan yang dilakukan secara manual.

Kemudian algoritma juga dapat mengidentifikasi tiap modul, memberikan nilai (scoring), mengambil data-data yang dibutuhkan seperti jenis-jenis aktivitas yang digunakan, nama modul, serta menentukan status keterpakaian modul. Aplikasi juga dapat menyimpan data-data yang telah didapat dari algoritma ke dalam database. Data yang terdapat di dalam database disajikan berupa dalam bentuk grafik yang dapat mempermudah pengguna dalam memahami informasi secara cepat dan akurat.

Proses pengujian dilakukan dengan cara membandingkan kategori keterpakaian yang dihasilkan dari proses text mining dengan hasil pemahaman pengguna. Adapun matakuliah yang diambil secara random sebanyak 5 mata kuliah dari 9 fakultas sehingga total matakuliah yang diuji sebanyak 45 modul. Kinerja algoritma dalam mengklasifikasikan dapat dihitung dengan membandingkan jumlah prediksi benar terhadap total keseluruhan modul yang diujikan. Dari 45 data uji yang dilakukan, terdapat 40 modul yang diklasifikasi secara benar dan 5 yang salah. Hasil pengujian dapat dilihat pada Tabel 1. Sehingga nilai kinerja akurasi algoritma sebesar $\mathbf{8 8 , 8 9 \%}$. Hal ini dapat dikategorikan algoritma dapat bekerja secara baik.

Beberapa error atau kesalahan dalam mengklasifikasikan dapat dianalisa lebih lanjut penyebabnya. Terdapat beberapa penyebab terjadinya kesalahan atau error dalam klasifikasi seperti tampilan modul dibuat sedikit berbeda dengan model collapse atau bungkus sehingga pada setiap pertemuan untuk modul tersebut hanya terlihat judul pertemuan saja sedangkan aktivitas atau fiturnya tidak terlihat. Hal ini mengakibatkan sistem akan mengkategorikannya sebagai tidak digunakan, padahal seharusnya digunakan. Pada kasus lainnya semua aktivitas digunakan secara lengkap namun diletakan pada satu pertemuan saja. Sistem akan menggolongkan sebagai digunakan, padahal seharusnya termasuk modul yang tidak digunakan.

\section{Kesimpulan dan Saran}

Setelah dilakukan kegiatan penelitian ini, dapat disampaikan beberapa hasil penelitian yang disajikan dalam bentuk kesimpulan. Pertama, penelitian ini telah berhasil membangun algoritma yang dikemas dalam bentuk aplikasi. Algoritma yang dibangun menggunakan pendekatan metode text mining untuk mengolah data berupa kode HTML menjadi informasi penting. Informasi penting tersebut berupa nilai (score) berdasarkan parameter ketersedian fitur-fitur File, Lesson, Forum, Quiz, Assignment, dan RPS pada suatu modul. Dari hasil nilai (score) tersebut dapat diklasifikasikan kategori keterpakaian suatu modul apakah sekedar Diaktifkan atau Digunakan dalam perkuliahan. Proses klasifikasi keterpakaian modul tersebut dilakukan pada tiap semester. Total modul yang diklasifikan secara otomatis sebanyak 4714 data atau modul. Kedua, berdasarkan hasil pengujian yang dilakukan, didapat kinerja akurasi algoritma dalam mengklasifikan data secara benar sebesar $88,89 \%$. Hal ini dapat dikatakan kinerja akurasi algoritma bekerja secara baik. Selain kinerja akurasi algoritma, terdapat pula beberapa error atau kesalahan dalam proses klasifikasi. Kesalahan atau error tersebut terjadi karena tampilan yang tidak standar pada saat menampilkan detail modul. Hal ini dapat menjadi masukan atau saran dapat pengembangan algoritma kedepannya..

\section{Daftar Pustaka:}

Afriansyah, H. (2019): Pengembangan Model Pembelajaran Virtual (MPV) Berbasis Video ELearning Moodle. Jurnal Bahana Manajemen Pendidikan

Putri, S. E. Putri, Hamuddin, B. Nursafira, M. S. and T. Derin, (2020): Discourse Analysis in ELearning-Based Course Using Moodle Platform: An Experimental Design. Journal of Research and Innovation in Language.

Inggriyani, F. Fazriyah, N and Purbasari, A. (2019) Penggunaan E-learning Berbasis Moodle bagi KKG Sekolah Dasar di Kecamatan Lengkong Kota Bandung, Jurnal SOLMA

Fatmawati, S. (2019): Efektivitas Forum Diskusi Pada E-Learning Berbasis Moodle Untuk Meningkatkan Partisipasi Belajar, Refleksi Edukatika: Jurnal Ilmiah Kependidikan, vol. 9, no. 2 
Muhammad, H. R. Eka Murtinugraha, and Sittati Musalamah. (2020): Pengembangan Media Pembelajaran E-Learning Berbasis Moodle Pada Mata Kuliah Metodologi Penelitian, Jurnal

Sara, K. Witi, F. L. and A. Mude, (2020): Implementasi E-Learning Berbasis Moodle di Masa Pandemi Covid 19. Journal Of Administration and Educational Management (ALIGNMENT), vol. 3, no. 2

A. Priyanto and M. R. Ma'arif, (2018) Implementasi Web Scrapping dan Text Mining untuk Akuisisi dan Kategorisasi Informasi dari Internet (Studi Kasus: Tutorial Hidroponik) Indonesian Journal of Information Systems

Riski, B. W. Dwi, R. Nooraeni, T. Siahaan, and Y. Dhea, (2019) Analisis Text Mining dari Cuitan Twitter Mengenai Infrastruktur di Indonesia dengan Metode Klasifikasi Naïve Bayes,” Eigen Mathematics Journal

Pratama, E. E, Sastypratiwi H. and Yulianti, "Analisis Kecenderungan Informasi Terkait Covid-10 Berdasarkan Big Data Sosial Media dengan Menggunakan Metode Data Mining," Jurnal Informatika Polinema, vol. 7, no. 2, 2021, doi: 10.33795/jip.v7i2.453. Available: [Accessed: 10-Agustus-2021]

Deolika, A. Kusrini, K. and Lutfi, E. T. Luthfi, "Analisis Pembobotan Kata Pada Klasifikasi Text Mining," Jurnal Teknologi Informasi, vol. 3, no. 2, 2019.
Hidayatullah, F. (2016) Penerapan Text mining dalam Klasifikasi Judul Skripsi Seminar Nasional Aplikasi Teknologi Informasi," Seminar Nasional Aplikasi Teknologi Informasi (SNATi)

Somantri, O. Khambali, M. (2017) Feature Selection Klasifikasi Kategori Cerita Pendek Menggunakan Nä̈ve Bayes dan Algoritme Genetika. Jurnal Nasional Teknik Elektro dan Teknologi Informasi (JNTETI), 6(3), 301-306. 2017.

Hormansyah, D. S., Utama, Y. P. (2018) Aplikasi Chatbot Berbasis Web pada Sistem Informasi Layanan Publik Kesehatan di Malang dengan Menggunakan Metode TF-IDF. Jurnal Informatika Polinema

Prameswari, K. Setiawan, E. B. (2019) Analisis Kepribadian Melalui Twitter Menggunakan Metode Logistic Regression dengan Pembobotan TF-IDF dan AHP eProceedings of Engineering

Putri, S. V. (2020) Klasifikasi Multi Label Gaya Belajar VAK berdasarkan Perilaku Pembelajaran pada E-learning Menggunakan Metode Supervised Learning. Institut Teknologi Sepuluh Nopember

Ferdino, I. Ferdino, (2019) Rancang Bangun Aplikasi Website Pendukung Rekayasa Kebutuhan Menggunakan Naive Bayes Classifier untuk Klasifikasi User Feedback (Studi Kasus: E-Learning Universitas Multimedia Nusantara) (Doctoral dissertation, Universitas Multimedia Nusantara. 
Tabel 1. Perbadingan Hasil Pengujian Klasifikasi oleh Sistem dan Pengguna

\begin{tabular}{|c|c|c|c|}
\hline Fakultas & Mata Kuliah & Sistem & User \\
\hline \multirow{5}{*}{ Ekonomi } & Perekonomian Kalimantan Barat dan Perbatasan Kelas A & Digunakan & Digunakan \\
\hline & Permodelan Dalam Ekonomi Kelas C Reguler A & Digunakan & Digunakan \\
\hline & Analisis Bisnis Berbasis Laporan Keuangan Kelas B Intensif & Digunakan & Digunakan \\
\hline & Manajemen Keuangan Lanjutan Kelas B Intensif & Digunakan & Digunakan \\
\hline & Metode Kuantitatif Bisnis Kelas B Reguler B Malam & Aktif & Aktif \\
\hline \multirow{5}{*}{ MIPA } & Aljabar Linier Elementer Kelas A Reguler A & Digunakan & Digunakan \\
\hline & Fungsi Variabel Kompleks Kelas A Reguler A & Digunakan & Digunakan \\
\hline & Analisa Algoritma Kelas A Reguler A & Aktif & Digunakan \\
\hline & Fisiologi Mikroba Kelas B Reguler A & Aktif & Aktif \\
\hline & Biologi Sel \& Molekuler Kelas A Reguler A & Aktif & Aktif \\
\hline \multirow{5}{*}{ Teknik } & Analisis dan Perancangan Sistem Kelas B Reguler A & Digunakan & Digunakan \\
\hline & Analisis Struktur Metode Matriks Kelas A Reguler A & Digunakan & Digunakan \\
\hline & MATEMATIKA TEKNIK II Kelas A Reguler A & Digunakan & Digunakan \\
\hline & Pengelolaan Kualitas Lingkungan Kelas B Reguler A & Aktif & Aktif \\
\hline & genap 2020/2021 Otomata Kelas A Reguler A & Aktif & Aktif \\
\hline \multirow{5}{*}{ IKIP } & Demografi Kelas A & Digunakan & Digunakan \\
\hline & Belajar dan Pembelajaran Kelas A Reguler A & Digunakan & Digunakan \\
\hline & Mikologi Kelas A Reguler A 2021 & Digunakan & Digunakan \\
\hline & Sosiologi Olahraga Kelas A Reguler A & Aktif & Aktif \\
\hline & Sejarah Kebudayaan Indonesia Kelas A Reguler A & Aktif & Digunakan \\
\hline \multirow{5}{*}{ Hukum } & Hukum Pidana Kelas A Reguler B & Digunakan & Aktif \\
\hline & Perbandingan Hukum Pidana Kelas A Reguler A & Aktif & Aktif \\
\hline & Kriminologi Kelas A Reguler A & Aktif & Aktif \\
\hline & Hukum Pidana Di Luar Kodifikasi Kelas D Reguler A & Aktif & Aktif \\
\hline & Hukum Lingkungan Kelas C Reguler B & Aktif & Aktif \\
\hline \multirow{5}{*}{ ISIPOL } & Public Relation Kelas B Reguler A & Digunakan & Digunakan \\
\hline & Sejarah Sosial Politik Indonesia Kelas A Reguler A & Digunakan & Digunakan \\
\hline & Teori Hubungan Internasional Kelas B Reguler A & Digunakan & Digunakan \\
\hline & Pengelola Arsip Elektronik Kelas A D3 & Digunakan & Digunakan \\
\hline & Manajemen Perkantoran Modern Kelas A D3 & Aktif & Aktif \\
\hline \multirow{5}{*}{ Pertanian } & Teknik Pengelolaan Air Pertanian Kelas C Reguler & Digunakan & Digunakan \\
\hline & Cekaman Lingkungan Pada Tanaman Kelas A Reguler & Digunakan & Digunakan \\
\hline & Manajemen Species Asli Kelas A Reguler A & Digunakan & Digunakan \\
\hline & Manajemen Agribisnis Kelas B Reguler A & Aktif & Aktif \\
\hline & Agroklimatologi Kelas B Reguler A & Aktif & Digunakan \\
\hline \multirow{5}{*}{ Kehutanan } & Pertumbuhan Pohon dan Kualitas Kayu Kelas E Reguler A & Digunakan & Digunakan \\
\hline & Kimia Kayu Kelas E Reguler A & Digunakan & Digunakan \\
\hline & Ekologi Hutan Kelas E Reguler A & Digunakan & Digunakan \\
\hline & Botani Kelas C Reguler A & Aktif & Aktif \\
\hline & Agroforestry Kelas A Reguler A & Aktif & Digunakan \\
\hline \multirow{5}{*}{ Kedokteran } & Farmakoterapi Gangguan Imunologi dan Onkologi & Digunakan & Digunakan \\
\hline & Aplikasi Standar Pelayanan Kefarmasian & Digunakan & Digunakan \\
\hline & Keperawatan Medikal Bedah II Kelas A Reguler A & Digunakan & Digunakan \\
\hline & Prakt. Biofarmasetika - Farmakokinetika Kelas A2 Reg A & Digunakan & Digunakan \\
\hline & Keperawatan Dasar 2 Kelas APK Reguler B & Aktif & Aktif \\
\hline
\end{tabular}

